\title{
Control of Additives in Copper Electrorefining by Using the Hull Cell Test
}

\author{
by Koji ANDO ${ }^{\mathrm{a}}$, Naoyuki TSUCHIDA ${ }^{\mathrm{b}}$ and Hiroshi KOMI ${ }^{\mathrm{c}}$
}

a. Niihama Research Laboratories, Sumitomo Metal Mining Co., Ltd., Niihama-shi 792-0002, Japan

b. Non-Ferrous Metal Division, Sumitomo Metal Mining Co., Ltd.

c. Niihama Copper Refinery, Sumitomo Metal Mining Co., Ltd.

To produce high-quality electrolytic copper, the influence of additives on copper electrodeposition was studied, and the design and control of the additives in copper electrorefining were discussed in the present paper. The experiment for the influence of the additives such as glue, thiourea and chloride ion in the copper electrolyte on the surface roughness in electrodeposition were carried out with the Hull Cell test and the practical scale test, and the additives strength was defined by the concentrations of these additives, which was clarified to be useful for controlling the copper electrolyte. An expression as a function of the copper concentration in the electrolyte, the additives strength, the current density and the electrode space was also derived for obtaining the smooth electrodeposition, which is of great help in controlling the copper electrolysis.

KEY WORDS : Glue, Thiourea, Chloride Ion, Additives Strength, Surface Roughness, Hull Cell Test

\section{1. 緒}

\section{論}

銅電解では，カソード表面に粒などの凹凸が発生すると，そこ に電流が集中して流れて粒が成長しアノードとショートして電力 を損失する。また，不純物の多い電解液やアノードスライムを巻 き込んでカソードの不純物が増加するなどの影響が生じる。さら に，電解槽から引き揚げられたカソードをそのまま製品とする場 合，粒の多いカソードはハンドリングの面でも好まれない。この ような理由により，工業的な銅電解では，粒のない平滑なカソー ドを得ることが電気銅の品質管理上重要であるが，銅イオンと硫 酸だけからなる電解液では平滑な電着を得るのは困難であり, 添 加剤の使用が久かせない。

しかしながら, 電解液に添加された微量の添加剤は電解液中で 分解し消費されていくので，その定量分析は困難であり，添加剤 の管理は経験に依拠して行われる場合が多い。添加剤が不足する と粒の発生を抑制できないが，過剩すぎても粒の発生を促進する など, 添加剤の効果を発揮する濃度範囲があり, 添加量の調整が 随時必要とされる。添加剤の評価は，電気銅の電着状態を目で見 て判断するのがもっとも確実であるが，銅電解でのカソードは電 槽中で数日間連続して通電されるため，引揚がるのを待つのでは 対応が遅れがちとなる。さらに, 電着状態に影響寸る要因には, 添加剂以外にも, 電解液組成, カソード歪, 電流バラッキ, 電解 液の給液や液温度など数多くあり, 添加剤の状態を的確に管理す ることは銅電解の大きな課題となっていた。

電解液中の添加剤の状態を評価する方法は種々提案されている1) が，再現性，測定精度，測定に要する手間などの多くの必要性を

* 2001 年 7 月 30 日受付 11 月 30 日受理

1. 普通会員 住友金属鉱山 (株) 新居浜研究所

2. 普通会員 Ph.D. 住友金属鉱山 (株) 金属事業本部

3. 住友金属鉱山 (株) 別子事業所精銅工場

[著者連絡先] FAX 0897-37-7179 (住友鉱山・新居浜研)

E-mail : kouji_andou@ni.smm.co.jp

キーワード : にかわ, チオ尿素, 塩化物イオン, 添加剤強度, 表面粗さ, ハルセ 儿試験

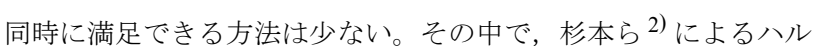
セル試験を利用した電解液の評価方法は，再現性よく比較的容易 に測定できる。この方法は，電着の表面粗さを測定することが特 徵であり，電解液の状態を表面粗さによって定量化することが可 能と考えられる。そこで本研究では, 実規模電解試験とハルセル 試験を適用して銅電析での添加剂の作用を解明することとし，併 せて, 銅電解で最適な添加剂の設計を可能とする管理指標を確立 することを目的とした。

\section{2. 試 験 方 法}

\section{$2 \cdot 1$ 実規模電解試験}

従来から行われてきた小型電解試験では, 電解に影響する様々 な要因を完全に再現することは難しいので, 本研究では, 添加剤 などの電解条件を変えた実規模試験で得た電気銅を観察し，同時 にその電解液をハルセル試験して添加剤の効果を評価した。

電解槽は幅 $1,250 \mathrm{~mm} \times$ 長さ $3,000 \mathrm{~mm} \times$ 平均深さ $1,500 \mathrm{~mm}$ のサイ ズの工業用電槽を実規模試験に使用した。1 槽当たりのアノードは 26 枚, カソードは 25 枚とし, いずれも実操業と同一品である。カ ソードの有効電着サイズは幅 $1,070 \mathrm{~mm} \times$ 縦 $1,050 \mathrm{~mm}$ になる。ア ノードとアノードの電極間隔は $105 \mathrm{~mm}$ とした。アノードとカソー ドの厚みを除いた面間距離は通電の前半で $33 \mathrm{~mm}$, 後半で $40.5 \mathrm{~mm}$ となる。電解液も実操業用と同一のものを調製し, $60^{\circ} \mathrm{C}$ の温度で $15 \mathrm{l} / \mathrm{min}$ 給液した。アノードと電解液の代表組成を Table 1 に示 す。通電電流密度は $250 \sim 310 \mathrm{~A} / \mathrm{m}^{2}$ とし, 途中 1 回のカソード 交換を行って, 電流密度に応じて $370 \sim 460$ 時間通電した。通電 中はショート発生をチェックした。電解液は銅, 硫酸, 塩化物イ オンを毎日, 砒素, アンチモン, ビスマス等の不純物を $3 \sim 5$ 日 ごとにそれぞれサンプリングし, 滴定法や ICP を用いて分析した。

Table 1 Typical assay of electolyte and anode.

\begin{tabular}{l|ccccccc}
\hline & $\mathrm{Cu}$ & $\mathrm{H}_{2} \mathrm{SO}_{4}$ & $\mathrm{As}$ & $\mathrm{Sb}$ & $\mathrm{Bi}$ & $\mathrm{Ni}$ & $\mathrm{Pb}$ \\
\hline Electrolyte $\mathrm{g} / \mathrm{50}$ & 190 & 1.5 & 0.5 & 0.5 & 15.0 & - \\
Anode mass\% & 99.2 & - & 0.10 & 0.052 & 0.033 & 0.13 & 0.17 \\
\hline
\end{tabular}




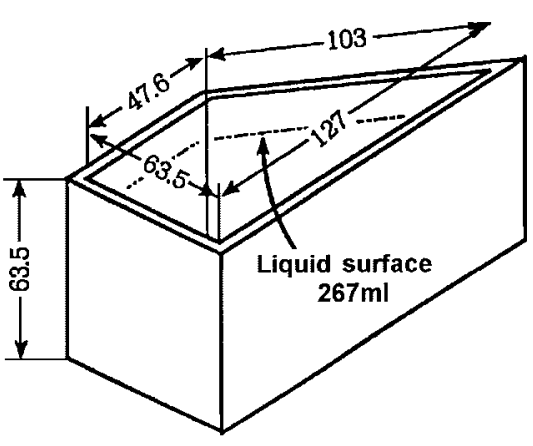

Fig.1 Schema of the Hull Cell

Table 2 Typical conditions of copper electrolysis.

\begin{tabular}{lc|cccc}
\hline Current density & $\mathrm{A} / \mathrm{m}^{2}$ & 250 & 260 & 297 & 310 \\
Glue & $\mathrm{mg} / \mathrm{l}$ & 1.48 & 1.92 & 2.22 & \\
Thiourea & $\mathrm{mg} / \mathrm{1}$ & 1.11 & 3.33 & 5.55 & \\
Chloride ion & $\mathrm{mg} / \mathrm{l}$ & 30 & 50 & & \\
\hline
\end{tabular}

通電終了後の電気銅は外観を目視で評価した。評価は, 1 枚の電 気銅の表裏をそれぞれ縦横 3 等分, 計 18 区画に区分し，区画ごと に $1 \sim 5$ 点で目視により採点した。採点基準は通常を 3 点として， 直径 $10 \mathrm{~mm}$ 程度の粒が数個以下であれば 4 点，全く無い場合を 5 点とし, 反対に粒が全体の $30 \%$ 以下にある場合を 2 点， $30 \%$ 以 上であったり製品にできないほど大きな粒がある場合を 1 点とし た。1 枚の電気銅の評価は $18 \sim 90$ 点の範囲となる。観察後の電 気銅は電着量を測定し, サンプリングして硫黄, アンチモン, 鉛 などの不純物を ICP 法などによって分析した。

添加剤としては，にかわ，チオ尿素および塩化物イオンを使用 した。実操業では，添加剤としてチオ尿素 $60 \mathrm{~g} / \mathrm{Cu}-\mathrm{t}$ ，にかわ $80 \mathrm{~g}$ / Cu-t を使用するので，これらの量を基準の添加量 $(\times 1$ 倍 $)$ とし た。この場合, 電解給液中の濃度はそれぞれ $1.11 \mathrm{mg} / l, 1.48 \mathrm{mg} /$ $l$ となる。基準量と必要量との差を給液によって定量ポンプで連続 添加した。塩化物イオンは, 液濃度を見ながら, 必要量の塩酸を 純水に希勫して連続的に添加した。

\section{$2 \cdot 2$ ハルセル試験による電解液の評価方法}

ハルセル試験は，Fig.1 に示すような台形をした電解槽を用い， カソードとアノードを斜めに対面して通電するので，カソード上 の電流分布が偏る。その結果， 1 枚のカソードで広範囲な電流密 度による電着状態を観察できるのが特徴である。本試験のハルセ ル試験には, 液量 $267 \mathrm{ml}$ の電槽を使用した。アノードは, $0.7 \mathrm{~mm}$ 厚の電着銅板を $63 \mathrm{~mm} \times 63 \mathrm{~mm}$ の大きさに切断し，表面を $5 \%$ の 硫酸で軽く洗浄したものを用いた。カソードは，横幅 $100 \mathrm{~mm} \times$ 縦 $63 \mathrm{~mm}$ で，板厚 $0.3 \mathrm{~mm}$ の圧延銅板の表面を $30 \%$ の燐酸ナトリウ 厶溶液と $5 \%$ の硫酸によって洗浄したものを用いた。アノードと カソードをそれぞれ 1 枚ずつを電槽にセットした。電解液は電槽 内ならび給排液から採取した。電槽内の液は，電槽の中央部で液 面からの深さが 100,500 ならびに $900 \mathrm{~mm}$ となる位置からスポイ 卜で採取した。通電期間中 $2 \sim 3$ 日ごとに電解液を採取したので 1 回の実規模試験で実施したハルセル試験は $18 \sim 24$ 回に及んだ。 採取した電解液はハルセル槽にそのまま移し入れ，蓋をして $60^{\circ} \mathrm{C}$ のウオーターバス中で保温しながら $2 \mathrm{~A}$ の電流で 60 分間通電し た。一般のハルセル試験では通電中に攪拌したり窒素ガスを吹き 込むことが多いが，カソード表面の分極が減少し添加剤による影 響をかえって判別し難くするので，本試験では攪拌やガス吹きこ みを省略した。通電終了後, カソードを引揚げて表面を純水なら びにメチルアルコールで洗浄し冷風で乾燥した。ハルセルカソー ド上で電流密度が $20 \mathrm{~A} / \mathrm{m}^{2}$ から $800 \mathrm{~A} / \mathrm{m}^{2}$ に相当する部分の表面 粗さを, 触針式表面粗さ計 (ミットヨ製 SURFTEST-201 型)を使

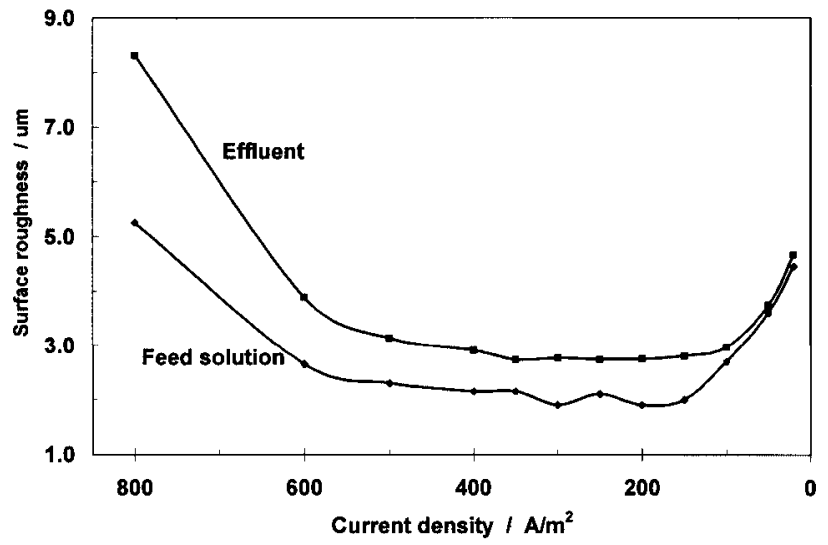

Fig.2 Surface roughness on the Hull Cell cathode for feed solution and effluent against current density.

用して測定した。測定長を $0.8 \mathrm{~mm}$ とし, 表面粗さを十点平均粗さ $(R z)$ で評価した。

\section{3. 試験結果ならびに考察}

\section{$3 \cdot 1$ 添加剤による電着表面粗さへの影響}

実規模試験では, 電流密度, にかわ濃度, チ才尿素濃度, 塩化 物イオン濃度を対象として, Table 2 に示寸水準を組み合わせて通 電した。今回の試験条件範囲ではアノードでの不働態化などの異 状は発生しなかった。

実操業での電解給液と排液に対してハルセル試験をした場合の カソード上の各電流密度に相当する部分での電着表面粗さを Fig.2 に示す。 $2 \mathrm{~A}$ の通電電流では 1 枚のハルセルカソード上でお おむ称 $10 \sim 1,000 \mathrm{~A} / \mathrm{m}^{2}$ の電流密度の状態が観察できる。しかし, 高電流密度側では, 限界電流密度に近いことから, 銅粉が電析し やすく表面粗さがばらつきやすくなる。一方, 低電流密度側では, 電着が不均一なため, 供試カソードの表面粗さの影響が大きく測 定誤差となりやすい。

さらに実規模電解では電槽内の複数のカソードに電流が分かれ て流れるため電流分布のばらつきが生じる。電槽内の各カソード の電着量から電流分布のばらつきを実測すると, 平均電流密度 $(D k x)$ に対寸るばらつき $(\sigma / x)$ は $0.05 \sim 0.08$ 程度であった。工業 的な通電電流密度の最高が $400 \mathrm{~A} / \mathrm{m}^{2}$ として, $3 \sigma$ の範囲内にばら ついているとすると, 式 (1) から槽内カソードの最高の電流密度 $\left(D k_{\max }\right)$ は $500 \mathrm{~A} / \mathrm{m}^{2}$ 程度に達していると考えられる。そこで, 八 ルセルカソード上で電流密度が $150 \sim 600 \mathrm{~A} / \mathrm{m}^{2}$ に相当する位置 の表面粗さを評価対象とした。

$D k_{\max }=\{(\sigma / x) \times 3+1\} \times D k x$

1 回の実規模試験の期間中にハルセル試験を $18 \sim 24$ 回行うと, 表面粗さの測定数は $144 \sim 192$ 点になる。同一添加剤組成による 実規模試験でのハルセルカソードの表面粗さの度数分布の実測值 の一例を Fig.3 に示すが，このように測定数が増加すると表面粗 さの度数分布は正規分布に近似できると考えられる。チ才尿素と にかわ添加量を変化させた場合の表面粗さの度数分布を正規分布 に補正した一例を Fig.4 に示す。チオ尿素が増加すると表面粗さ のピークは小さい方向に移動するとともにピーク高さが上昇し, 一方にかわを増加した場合には, 表面粗さとそのピーク高さの変 化は小さい様子が観察される。

ここで, 電着面の平滑さは, 横軸の表面粗さ $(R z)$ の平均值の小 ささで表現できる。一方, 縦軸のピークが高いほど表面粗さが集 中していることになり，それだけばらつき $(\sigma)$ が小さいことにな る。ばらつきが小さいことは均一電着性が良いことを意味すると 


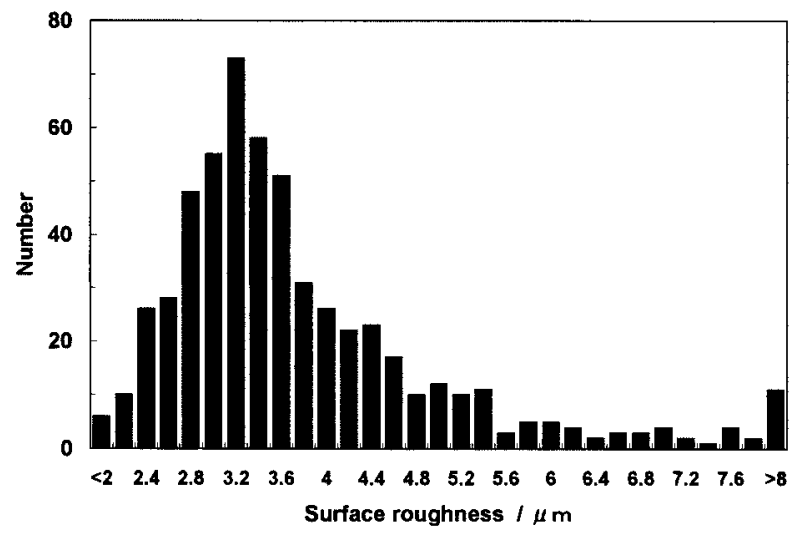

Fig.3 Distribution of surface roughness on the Hull Cell cathode.

(a) Thiourea

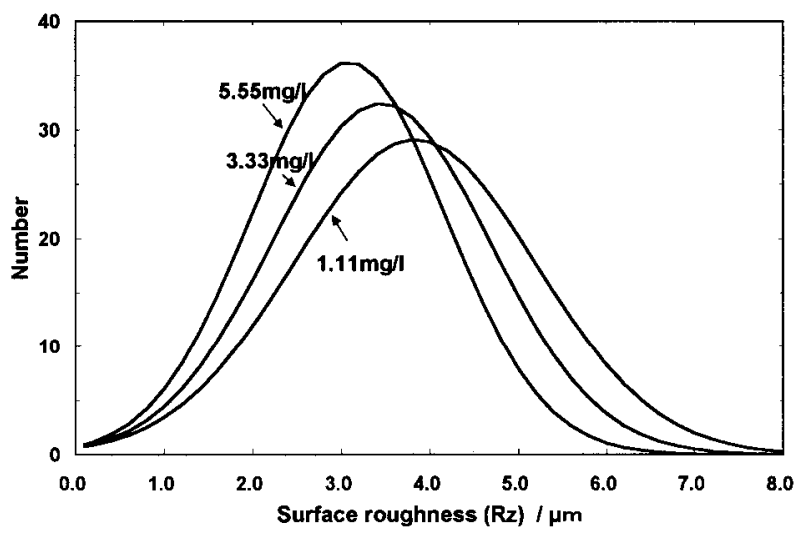

(b) Glue

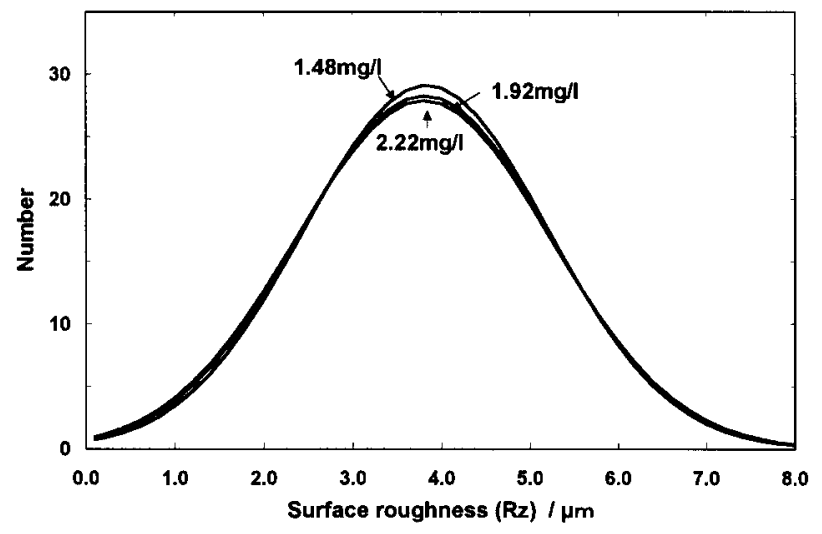

Fig.4 Distribution of surface roughness for Thiourea (a) and Glue (b).

解釈できる。

各試験における電解液中のにかわ, チ才尿素ならびに塩化物イ オンの条件に対する電解液の表面粗さと度数分布との関係につい て重回帰分析を行い, 添加剤組成と電着表面粗さに関して式 (2), (3) の関係が得られた。

$R z=-0.208 C_{\mathrm{tu}}-0.078 C_{\text {glue }}-3.115 \times 10^{-3} C_{\mathrm{Cl}}+4.160 \cdots \cdots$
$\sigma=-0.075 C_{\mathrm{tu}}+0.194 C_{\mathrm{glue}}-14.61 \times 10^{-3} C_{\mathrm{Cl}}+1.742 \quad \cdots \cdots$

$C_{\mathrm{tu}}, C_{\mathrm{glue}}, C_{\mathrm{Cl}}$ はそれぞれ電解液中のチ才尿素，にかわ，塩化 物イオンの添加濃度 $(\mathrm{mg} / \mathrm{l})$ である。添加剤は平滑な電着を均一に 得るのが本来の目的であることから, 式 (2), (3) の $R z$ とをを両方 とも小さくする添加量の組み合わせほど幅広い電流密度で最小の 電着表面粗さが得られ, 添加剤の効果が強いと見な寸ことができ る。このため, Fig.5 に示すように, $\sigma$ の逆数と $R z$ によるべクトル

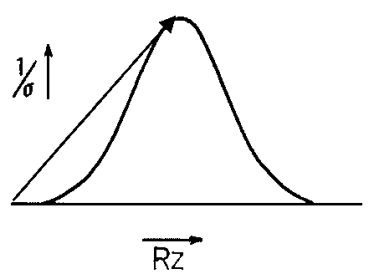

Fig.5 Schema of the additives strength.

Table 3 Orientation on copper deposition.

\begin{tabular}{ccc|ccc}
\hline \multicolumn{2}{c}{ Additives } & $\mathrm{mg} / \mathrm{l}$ & \multicolumn{3}{|c}{ Orientation } \\
Glue & T.U. & $\mathrm{Cl}^{-}$ & $(111)$ & $(200)$ & $(220)$ \\
\hline 0 & 0 & 0 & 0.08 & 0.08 & 8.70 \\
5 & 0 & 0 & 0.17 & 0.24 & 7.87 \\
0 & 4 & 0 & 0.88 & 1.52 & 0.75 \\
\hline 5 & 4 & 0 & 0.83 & 1.68 & 0.72 \\
5 & 4 & 30 & 0.87 & 1.52 & 0.85 \\
5 & 4 & 100 & 0.89 & 1.47 & 0.83 \\
\hline \multicolumn{3}{l}{ Rolled copper } & 0.40 & 1.24 & 3.57 \\
\hline
\end{tabular}

Orientation index $(\mathrm{I} / \Sigma \mathrm{I}) /(\mathrm{STAD} . \mathrm{I} / \mathrm{STAD} . \Sigma \mathrm{I})$

で添加剤の強度を定義し, 式 (4) で得られる值 (Ip) を電解液中の 添加剤の管理指標とした。

$I p=\left[(1 / R z)^{2}+(1 / \sigma)^{2}\right]^{1 / 2}$

ここで, 式 (2), (3) の各項の係数の值から, 電解液中の添加剤 濃度に関していくつかの特徵が見出される。塩化物イオンは表面 粗さに及ぼす影響が大きく, 塩化物イオン濃度を上昇することは 式 (2) と式 (3)での $R z$ と $\sigma$ をともに小さし, 式 (4) で表した添加 剂強度を効果的に増加することが示唆される。また, にかわ濃度 が上昇すると式(3)での $\sigma$ 夺きくなり添加剤強度は低下すること から, 添加剤強度を上昇して電着表面を改善するには, チ才尿素 とにかわの添加割合を固定せず機能に応じて個々に調整すべきと いえる。

にかわの役割に関して, 結晶成長の速い面に優先的に吸着して 電析速度を低下させることで粒成長を抑え, この結果平滑な電着 が得られると従来考えられてきた。しかし表面粗さのばらつきに 関する式 (3) の結果はこの考えと矛盾する。そこで銅電析の配向 性一及ぼす添加剤の影響について下記のような検討を試みた。

添加剂の配向性一の影響に関しては O'keef らの報告 ${ }^{3)}$ がよく知 られている。O'keef らによると, 電析速度の速い面は最終的に電 析の遅い面に組み込まれるので配向面となるのは電析速度の遅い 面である。すなわち, 添加剤が吸着して電析速度が低下寸るとそ の面が配向面となるので, 配向性を測定することで添加剤の効果 を知ることができると考えられる。そこで電極サイズが $140 \mathrm{~mm} \times$ $140 \mathrm{~mm}$ の圧延銅板をカソードに使用した小型試験によって, 電流 密度を $220 \mathrm{~A} / \mathrm{m}^{2}$, 電解液の銅濃度を $45 \mathrm{~g} / l$, 硫酸濃度を $190 \mathrm{~g} / l$ と して 24 時間通電し, 初期電着の配向性に及ぼす添加剂の影響を調 查した。Table 3 に添加剤組成に対する配向性の変化を示す。電着 前の圧延銅板の配向性は, (220)> (200)>(111) である。添加剤を使 用しないで電析すると, (220) 面の配向性がさらに増加するので (220) 面での電析速度が低下していることが分かる。この電解液に にかわを $5 \mathrm{mg} / l$ 添加すると (220) 面の配向性が若干低下し, (111), (200) 面の配向が強くなる。すなわち, にかわが成長速度の速い面 の電析を抑え, その分 (220) 面の電析が促進されると考えられる。 これに対してチオ尿素を $4 \mathrm{mg} / \mathrm{l}$ 添加した場合には, にかわとは逆 に(220) 面の配向性が大幅に低下し, (111)，(200) 面の配向指数が 増加した。すなわち, チ才尿素は, (111), (200) 面の電析速度を減 少するか (220) 面の電析を促進して, 各面の電析速度を均一化し 電着組織を微細にすると考えられる。にかわとチオ尿素では電析 の促進される面が異なるが, 塩化物イオンを増加すると（220）面 


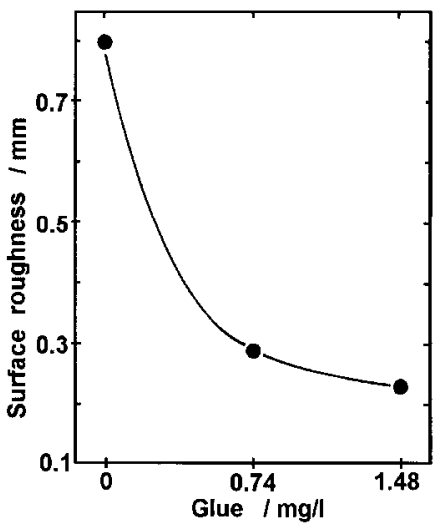

Fig.6 Surface roughness of electrolytic copper against glue concentration.

の配向性がわずかながら増加し，にかわの効果を減少する作用が あることが分かる。これは，にかわの吸着による分極作用を塩化 物イオンが抑制したためと考えられる。一方，(200) 面と (111) 面 の配向性の変化は互いに逆の傾向であり, チオ尿素と同じ挙動で もない。

にかわ添加の濃度の効果についてさらに検討するため，にかわ 濃度を減少した実規模試験を行い，得られた電気銅表面の条痕の 深さを測定した。にかわ濃度と電気銅表面での条痕の深さの関係 を Fig.6 に示すが，にかわを添加しなかった電解液で得た電気銅 の条痕深さは著しく大きい。しかし，にかわを実操業の半分の 0.74 $\mathrm{mg} / l$ まで添加した電解液での電気銅の条痕深さは, にかわ濃度が $1.48 \mathrm{mg} / /$ である実操業の場合とほとんど同じである。このこと は，実操業でのにかわはむしろ過剩気味であることを示唆し，こ れが式 (3) の関係として現れたと考えられる。にかわがカソード 表面に吸着し過ぎると電着を阻害して表面状態をかえって悪化さ せるので，にかわ添加の過度な増加は避けるべきと考えられる。

\section{$3 \cdot 2$ カソード不純物への影響}

前述の添加剂強度の回帰式により添加剂を設計することで，外 観の良好な電着が得られると予想される。添加剤の組み合わせに 関する本研究結果からは，にかわよりもチオ尿素の方が添加剤と しての効果が大きいことが示唆される。また一般に，にかわより もチオ尿素の方が管理しやすく細かな調整に適していると考えら れる。一方，三根ら ${ }^{4)}$ による，消費されたチオ尿素はカソード 表面で分解し，その結果電気銅中の硫黄濃度が増加寸る。このこ とから，チ才尿素の添加による電気銅中の硫黄濃度上昇に対する 注意が必要である。

Saban ら ${ }^{5)}$ によるにかわ消費速度の試算をチ才尿素にも適用す ると, チ才尿素添加量の増加に伴う電気銅中の硫黄濃度は式 (6)で 表せる。

$$
L=D C_{\mathrm{TU}} A / \sigma \delta
$$

$S=L \times 0.421 \times E / W$

ここで, $L$ はチ才尿素の消費速度 $(\mathrm{kg} / \mathrm{sec}), D$ は拡散係数で, 今 回はにかわと同じ $2 \times 10^{-10} \mathrm{~m}^{2} / \mathrm{sec}$ と仮定した。 $C_{\mathrm{TU}}$ はバルクでの チ才尿素濃度 $\left(\mathrm{kg} / \mathrm{m}^{3}\right), A$ は電極面積 $\left(\mathrm{m}^{2}\right), \delta$ はカソード表面の拡 散層厚さで $0.1 \times 10^{-3} \mathrm{~m}$ とした。 $S$ は電気銅中の硫黄濃度 $(\mathrm{ppm})$, $W$ は電着銅量 $(\mathrm{g}), E$ は供給したチ才尿素が電気銅に取り込まれる 効率である。チオ尿素が通常 $1.11 \mathrm{mg} / l(60 \mathrm{~g} / \mathrm{Cu}-\mathrm{t})$ の添加量では, 電気銅の硫黄濃度は平均 $3 \mathrm{ppm}$ であったことから，E は約 $26 \%$ と 見積もれる。添加量を 1.5 倍の $1.67 \mathrm{mg} / \mathrm{l}(90 \mathrm{~g} / \mathrm{Cu}-\mathrm{t})$ に増加すると 電気銅の硫黄濃度は $3 \mathrm{ppm}$ から $4.4 \mathrm{ppm}$ 一上昇すると試算され, こ の值は, 本試験での電気銅の硫黄濃度の $4 \sim 5 \mathrm{ppm}$ とほぼ一致した。 電気銅中の硫黄濃度は, Fig.7 に示すように，チ才尿素供給量が
少ないほど，液温が高いほど低下傾向である。この現象は，電解 液の液温を上昇するとチオ尿素の塩化物イオンなどによる分解が 促進されるため, あるいは, チオ尿素が銅イオンと錯形成して反 応する割合が低下するためと考えられる。Fig.7 の結果より, チオ 尿素を増加しながら電気銅の硫黄濃度を $3 \mathrm{ppm}$ 前後に抑制するに は, 通常 $60^{\circ} \mathrm{C}$ 前後の電解液温度を $64^{\circ} \mathrm{C}$ 程度にまで上昇すること が必要と考えられる。

式 (2)，（3）からは塩化物イオンの増加によっても添加剤強度は 増加する。このため, チオ尿素の増加にあわせて塩化物イオン濃 度を上昇寸ることでも硫黄濃度の増加を抑えた電気銅が得られる と考えられる。塩化物イオン濃度が $50 \mathrm{mg} / l$ と $60 \mathrm{mg} / l$ の場合で の電気銅の硫黄濃度を Fig. 8 に示すが, $60 \mathrm{mg} / l$ の塩素濃度の方が チオ尿素供給量を増加しても電気銅中の硫黄濃度の上昇を抑制で きることがわかる。

\section{$3 \cdot 3$ 電解液組成による電気銅外観への影響}

添加剤強度が，電気銅の外観やその他の電解成績に及ぼす影響 を把握するため, 実規模試験で添加剂強度, 前半と後半の通電で のアノードとカソード間の面間距離，電解液銅濃度，電流密度の 各要因を変化させて, 電気銅外観との関係を測定した。その結果, 各要因を重回帰分析し添加剤強度と電気銅の外観評価に関して式 (7) が得られた。

$H=21.1 I p+0.397 L+5.18\left(C_{\mathrm{Cu}} / D k\right) \times 1,000+25.38$

$H: 90$ 点満点で目視評価した電気銅の外観点

$I p:$ 添加剂強度

$L:$ アノードとカソードの初期面間距離 $(\mathrm{mm})$

$C_{\mathrm{Cu}}:$ 電解液の銅濃度 $(\mathrm{mol} / l)$

$D k:$ カソード電流密度 $\left(\mathrm{A} / \mathrm{m}^{2}\right)$

実規模試験で添加剤量，アノードとカソードの面間距離，電流

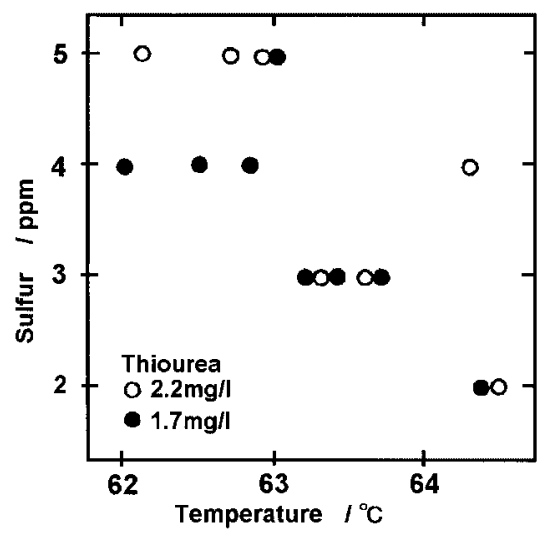

Fig.7 Influence of thiourea and electrolyte temperature on the sulfur grade.

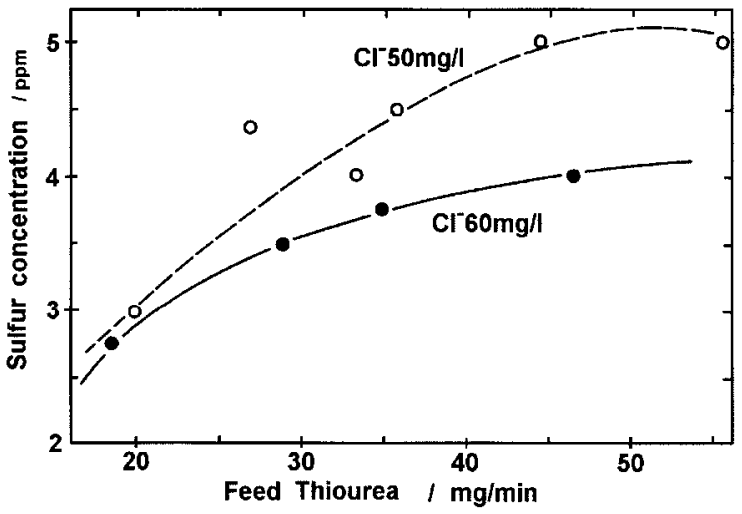

Fig.8 Influence of thiourea and chlorine concentration on the sulfur grade. 


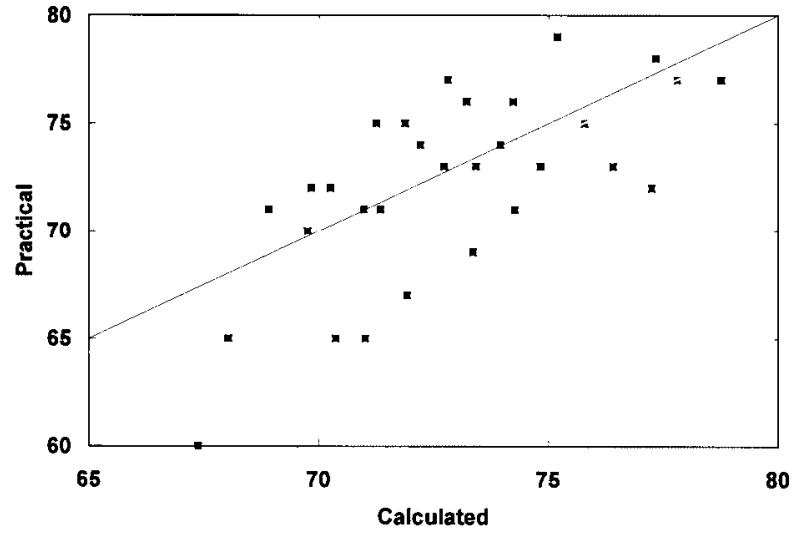

Fig.9 Calculated and actual values of electrolytic copper points.

密度, 電解液の銅濃度について電気銅を目視観察した外観評価と, 電解条件から式 (7) を用いて計算した外観評価点との関係を Fig.9 に示寸が，両者にはかなりよい相関がみられる。Fig.9 中では計算 值よりも実測值が低い場合も示されているが，これらは，式(7)の 計算において一定と仮定したカソード歪や電流分布が変化した影 響と考えられる。

以上の結果より，添加剤の組み合わせの最適化により電気銅表 面状態の改善がはかれることが示唆された。そこで一例として, 電流密度を $300 \mathrm{~A} / \mathrm{m}^{2}$ として 90 点満点で 72 点以上の電気銅外観 を得るのに必要な添加剤条件について検討した。式 (7) に示され ているように，同一の外観評価とすれば電解液の銅濃度を増加す ると添加剤強度は少なくて済む。しかし銅濃度の過度な増加は不 働態化を発生する可能性がある。電解液の銅濃度を $48 \mathrm{~g} / l$ とした 場合, 添加剤強度を 0.97 以上と寸ることが必要となる。この条件 を満たす添加剤量の組み合わせを考えると，チ才尿素の増加によ る方法以外では，にかわを減少寸ることも一つの選択肢と考えら れる。しかし，にかわは, Fig.6に示したように, $0.7 \mathrm{mg} / l$ 程度の 添加は表面の平滑性を維持するためにも必要である。一方, 塩化 物イオンの上昇も添加剤強度の確保に有効であるが, 設備の耐蝕 性やにかわの分解を過剩に促進寸る恐れがあるので, $60 \mathrm{mg} / \mathrm{l}$ 程 度が上限と考えられる。この例の場合, にかわ $1.48 \mathrm{mg} / l$, チ才尿 素 $1.67 \mathrm{mg} / l$, 塩化物イオン $48 \mathrm{mg} / l$ とすると所定の添加剤強度を満 たし，電気銅内の硫黄濃度にもほとんど影響しないと考えられる。 添加剤強度による管理を実操業の電解槽の一部ないし全槽に適
Table 4 Typical results of practical test.

\begin{tabular}{|c|c|c|c|c|c|c|c|}
\hline $\begin{array}{l}\text { Current } \\
\text { density }\end{array}$ & $\begin{array}{r}\text { Additives } \\
\text { strength }\end{array}$ & $\begin{array}{l}\text { Straightness } \\
\text { of starting } \\
\text { sheets }\end{array}$ & $\begin{array}{l}\mathrm{Cu} \text { in ele } \\
\text { ctrolyte }\end{array}$ & Short & Yield & Nodulation & $\begin{array}{c}\text { Surface } \\
\text { smoothness }\end{array}$ \\
\hline $\mathrm{A} / \mathrm{m}^{2}$ & & $\mathrm{~mm}$ & $\mathrm{~g} / 1$ & $\%$ & $\%$ & $\%$ & point \\
\hline 265 & 0.93 & $<10$ & 50 & 0.58 & 99.7 & 0.56 & 78.3 \\
\hline 275 & 0.94 & $<10$ & 50 & 0.16 & 100 & 1.27 & 75.6 \\
\hline 285 & 0.94 & $<10$ & 50 & 0.46 & 100 & 0.56 & 85.5 \\
\hline 300 & 0.81 & 14 & 46 & 0.66 & 99.2 & - & 48.6 \\
\hline 300 & 0.82 & $<10$ & 50 & 0.41 & 99.9 & 0.66 & 69.8 \\
\hline 300 & 0.96 & $<10$ & 50 & 0.25 & 100 & 0 & 80.5 \\
\hline
\end{tabular}

用し，長期間にわたる効果を確認した。結果を Table 4 に示すが, カソード矯正による歪低減の効果も併せることで外観ならびに ショートや粒発生の低減など品質向上の効果は明らかであり, 添 加剤の設計方法が有効であることを検証できた。また, 電気銅の 硫黄濃度も平均 $4 \mathrm{ppm}$ とほぼ計算通りであった。

\section{4. 結 論}

銅電解において添加剤設計の方法を確立し管理指標とするため に, 添加剤による電着表面状態への影響を検討し以下の知見を得 た。

（1）ハルセルカソードの表面粗さとばらつきから，銅電析に及 ぼす添加剤の影響を添加剂強度として定義した。

（2）電気銅の電着状態に影響する添加剂強度, 電解液の銅濃 度, 電流密度, アノードーカソードの面間距離の相互の関係式を 得た。

（3）添加剤強度の概念と電気銅の外観に及ぼす関係式は, 日常 の電解液管理の指標にとどまらず高電流密度化などの電解条件の 変更にも対応して, 通電に先立って添加剤を設計寸ることにも適 用できる。

\section{引用 文 献}

1) Belcha, V.K., Wang, Z.Z. and Krueger, D.W. : Glue Analysis and Behavior in Copper Electrolyte, Metallurgical Transaction, Vol.24B, p. 277-287, (1993)

2) 杉本誠人・安藤孝治・塚越幸夫・岡本信幸 : 資源・素材学会, 平成 5 年度春季 大会講演要旨集, p. 91-92, (1993)

3) O'keef. T.J and Hurst. L.R. : The Effect of Antimony, Chloride Ion and Glue on Copper Electrorefining, J. Appl. Electrochem., Vol. 8, p. 109-119, (1978)

4) 三根剛四郎・富永睦男・清山哲郎: 硫酸銅メッキ浴からの銅電着におけるチ才 尿素 $\left(\mathrm{C}^{14}, \mathrm{~S}^{35}\right)$ の共析, 電気化学, Vol. 35, p. 472-477, (1964)

5) Savan, M.D., Scott, J.D. and Cassidy, R.M. : Collagen Proteins in Electrorefining Rate Constant for Glue Hydrolysys and Effect of Molar Mass on Glue Activity, Metallurgical Transaction, Vol.23B, April, p. 125-133, (1992) 